Bisserka Veleva

Valentin Petroussenko

Sofia University "St.Kliment Ohridski"
821.163.2.09

https://doi.org/10.18485/filkult.2016.2.ch6

\title{
USE OF DIMINUTIVES IN THE BULGARIAN YOUTH LITERATURE, - THE NOVEL OF ELIN PELIN "YAN BIBIYAN"
}

Diminutives are important part of the lexical treasury in the languages but there are considerable differences about their use and the morpho-synthactic characteristics. It is important to study them as communication tools with specific features. Each language has different semantic use of diminutives and this is illustrated by the diversity and multiplicity of the lexical systems in the development of each language.

The object of present paper are the diminutive nouns taken from a youth novel of famous Bulgarian author Elin Pelin "Jan Bibijan. Amazing adventures of a kid" and its translation into German. This is part of my greater study of contrastive linguistic analysis of the Bulgarian and German diminutives on the basis of various literary works of Bulgarian and German writers and their respective translations into Bulgarian and German. It is aimed to see how these translations are reflecting the responsibilities of transforming the lexical and semantic richness of each language and the multiple levels of connotation in each culture.

Key words: Diminutives, Translation, Semantics, Bulgarian, German Language

The subject of the current paper concerns diminutive nouns, which belong to the bigger class of diminutives. They are taken from a children's novel "Jan Bibijan. Amazing adventures of a kid" (Пелин 1969) written in 1933. Its author is one of the most famous Bulgarian writers, who lived in the first half of the 20th century and is called Elin Pelin (1877-1949). The edition used for this research dates from 1969 . The second text as a basis for my analysis is the translation of this novel into German made by Hilde Grantscharowa (Pelin 1962).

This paper is part of my greater study - a contrastive linguistic analysis of the Bulgarian and German diminutives on the basis of various literary works of Bulgarian and German writers and their respective translations into Bulgarian and German. 
Our thesis in the present research is that language as a product of human development, in a very broad sense is in a constant relationship with the culture by which it was created. Thus the essential features of the culture model the language in the society and they always find a reflection in its structural and conceptual sides. This influence is present also in the most quickly developing component of the language domain lexicology, where an important place is given to diminutive nouns.

The basic concepts which play a role in the paper are: Culture and Intercultural Communication, Diminutives in Bulgarian and German.

\section{Culture and Intercultural Communication}

In the conditions of globalization the understanding of the term culture finds a projection in intercultural communication, a factor of essential importance for the

effectiveness of the translated texts. The academic concept of Intercultural Communication is that it consists of the following elements ( $\mathrm{SiM}$ ):

1.1. Culture - a set of behavioral models in the process of developing and realization of the individual as a social personality, where the language is one of most important means of communication among the people. (SiM 4.1.1., 1).

1.2. Communication - the use of systems of signs to exchange information (SiM 4.1.2., 2).

1.3. Intercultural Communication - understanding among different cultures.

The so called idea of horizontal separation could be demonstrated here, which is seen in different communities, for example, among the Bulgarians and Germans, and which is known as "inter-" or "intra-" communication. When the two cultures are present, and with the term "inter-" the principle of reciprocity among the cultures is emphasized (SiM 4.1.3., 3).

If the two texts created in the circumstances of two cultures and written in two different languages are compatible, we can draw two conclusions:

A) The original texts include features of the culture of the original holder of this culture; 
B) The translated text, presented in the language of the other culture, exhibits elements specific to the second culture. However, it is often compelled to keep some elements characteristic of the first culture, mostly of content nature, on which are superimposed the elements of the second culture (Велева 2014).

\section{Diminutives - theoretical notes}

Diminutives are an important part of the lexical treasury of languages. But there are considerable differences between languages regarding quantity, morpho-synthactic and semantic characteristics or the use of diminutive nouns. As all immanent language units they show in communication a definite number of general and specific characteristics. This specificity of diminutives is typical of each language and that can be used as a criterion for differentiating languages from each other, concerning the system of lexical means as well as their use in real everyday speech. This phenomenon is closely connected with the similarities and multioptions of lexical structures but also with the extralinguistic differences in the cultures of native language speakers. The diminutive nouns as linguistic lexical elements are distinguished by their dual nature - they are characterized by a precisely defined form and a corresponding content.

\subsection{Formal features of diminution}

\subsubsection{In Bulgarian:}

The most essential formal principle among the Diminutive Nouns (DN) is based on affixes. The most commonly used diminutive suffixes are:

- $-60,-k 0,-40,-e u$ in the masculine;

- -ка, -ичка (-ица + -ка) -урка in the feminine;

- -е, -ле, -че, -це, -енце, -ице in the neuter (Андрейчин);

- мини- is a diminutive prefix (БАН, 66-68).

\subsubsection{In German:}

The most commonly used diminutive suffix today is -chen, more seldom -lein, other suffixes are -el/-erl in South Germany and Austria, -le/la/-li in Switzerland -ke and -tje of North German origin (Henzen, 140-155), according to Wellmann and also -el, -ling (Wellmann,124-125), hypocho- 
ristical $-i$ in personal names (Duden, 460), -iko, -ke, -el, -z (Schmidt, 249), as well as in words of foreign origin -ette,-ine,-ell,-it,-y-in personal names (Fleischer/Barz, 181). As prefixes are also considered Klein-, Liliput-, Liliputformat-, Mini- (Duden, 460).

\section{Diminutives - practical notes}

Diminutive nouns are a kind of semantic modification, in which the morphological changes can cause diminution or minimising of the word's meaning, so there are two types of diminishing.

In the culture and the language, in particular, diminutive nouns are distinguished by their own formal and conceptual side. In this study an emphasis of the research is placed on the structural peculiarities of diminutives which we have extracted from the above mentioned books.

The creation of the word formations is connected with the morphonology of languages, and it deals with the formal part of the language items, by including all the phonological means, like internal flexion, mutation, and Palatalization, which can be traced while analyzing the words. This is why here it is appropriate to underline the similarities and differences in the form of the diminutives in the two languages. The following facts are considered:

3.1. In the Bulgarian text there are $\mathbf{6 8}$ diminutive nouns, as follows: In the singular: 67

\subsubsection{Masculine $\mathbf{- 5}$}

-ко (2): синко (Пелин, 26), татқов (Пелин, 54)

-чо (1): Калоㅡ (Пелин, 41)

These two suffixes are directly added to the base. Both are found in addressing individuals of masculine gender, as well in common nouns, and personal names. The second suffix contains an emotional component, an expression of a tender relationship.

Here no change of the gender is encountered.

-ец (2): ветрец (Пелин, 77) пращеи* (Пелин, 115)

In the first noun the transition from a non-diminutive nouns to the diminutive form is connected with mutation $-я->-e_{--}^{-}$, known in German 
as Umlaut, which is caused by shifting the accent from the root - $я$ - to the suffix -ец, and the -ъ- apocope in the non-diminutive basic noun вяm $\underline{p}$. In the case of the second diminution we see registered the First Palatalization $-x->-u-$.

Here no change of the gender is encountered.

\subsubsection{Feminine $\mathbf{- 2 3}$}

-ка (8): долчинка (Пелин, 13), книжка* (Пелин, 53) колибка (Пелин, 22), купчинка (Пелин, 62), птичка (Пелин, 94), рибка (Пелин, 9), чашка (Пелин, 115)

All diminutives of this group have an - $a$ apocope, the diminutives marked with the sign * exemplify First Palatalization -2->-ж-, in the case of птич $к a \rightarrow-u_{-}>-4-$.

The indicated suffixes add to the diminutive meaning mainly the feature of 'physical diminution'.

Here no change of the gender is encountered.

-ица (6): глътичица* (Пелин, 56), дупчица* (Пелин, 66), къщица (Пелин, 26), майчица* (Пелин, 115), мравцица*(Пелин, 101), сестрица (Пелин, 95)

In all diminutives of this group an - $a$ apocope marks the non-diminutive basic nouns, and First Palatalization $-\boldsymbol{k}^{-}>\mathbf{-} \boldsymbol{-}$ - is observed.

Apart from the feature of 'physical diminution', this suffix adds a connotative component 'tenderness'.

Here no change of the gender is encountered.

-чица (1): кръвчица (Пелин, 92)

Here the suffix is added directly to the base, which ends in a consonant, and again no change of gender is encountered.

-ичка (8): вадичка (Пелин, 56), вратичка (Пелин, 32), главичка (Пелин, 94), горичка (Пелин, 11), рекичка (Пелин, 56), сестричка (Пелин, 103), стомничка (Пелин, 25), тревичка (Пелин, 13)

The suffix causes $-a$ apocope in all cases.

It is important to notice that this suffix is doubled, i.e. it is the product of the merge of two suffixes -ица + -ка, where the existing diminutive forms serve as proof in the cases of the following lexemes:

врата - вратица - вратичка (Пелин, 32)

глава - главица - главичка (Пелин, 94) 


$$
\begin{aligned}
& \text { гора - горица- горичка (Пелин, 11), } \\
& \text { река- рекица-рекичка (Пелин, 56) } \\
& \text { сестра - сетрица - сестричка (Пелин, 103) } \\
& \text { трева - тревица - тревичка (Пелин, 13) }
\end{aligned}
$$

It is interesting here that the first derived forms are the diminutives in the second column, and they contain the feature of 'physical diminution', and the additional connotative component 'tenderness', while the diminutives of the third column express predominantly 'physical diminution'.

Here also no change of the gender is encountered.

\subsubsection{Neutral - 39}

-че (21): баирче (Пелин, 11), врабче (Пелин, 65), градче (Пелин, 7), гробче (Пелин, 27), дворче (Пелин, 32), долапче (Пелин, 75), другарче (Пелин, 31), дяволче (Пелин, 9), изворче (Пелин, 97), кладенче (Пелин, 25), косъмче (Пелин, 65), портретче (Пелин, 25/6), рогче (Пелин, 12), таралежче (Пелин, 65), тебеширче (Пелин, 8), топче (Пелин, 65), трионче (Пелин, 9), трънче (Пелин, 42), цветче (Пелин, 109), циганче (Пелин, 40), цурче (Пелин, 13)

In the diminutives врабче, кладенче и шурче арpears the -ец аросоре in the non-diminutive basic word, namely врабец, кладенец and щурец.

In циганче the -ин аросоре is detected, in juxtaposition with the initial non-diminutive form циганин, while in цветче there is mutation $-я->-e-$, Umlaut, caused by transferring the accent from the root -я- to the suffix - чe.

The suffix changes the gender of all nouns - from masculine to the neuter:

баир > баирче, врабец > врабче, град > градче, гроб > гробче, двор > дворче, долап > долапче, другар > другарче, дявол > дяволче, извор > изворче, кладенец > кладенче, косъм > косъмче, портрет > портретче, рог > рогче, таралеж > таралежче, тебешир > тебеширче, топ > топче, трион > трионче, трън > трънче, цвят > цветче, циганин > циганче, щурец > щурче

-е (9): дребосъче* (Пелин, 82), камъче* (Пелин, 40), капаче*

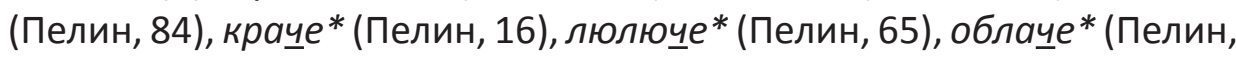

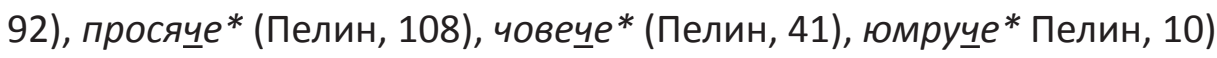

In all diminutives of this group compared with the non-diminutive basic nouns First Palatalization is observed $-\boldsymbol{k}->-\mathbf{-}$. 
The suffix changes all nouns - from masculine to neuter:

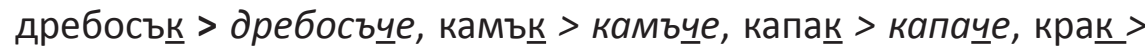

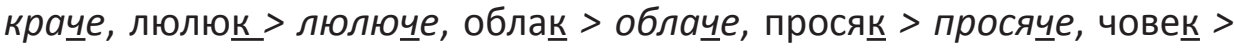
човече, юмрук् > юмручие

-це (3): дръвце (Пелин, 54), рогце (Пелин, 106/7), селце (Пелин, 53)

In дръвце the suffix causes in the normal basic noun a metathesis $-ъ p->-p ъ-, \partial ъ p в о>\partial p ъ в u e$, as well as the -o apocope.

Here the shift from masculine to neuter is detected only in poz > рогце, the two other diminutives are derived from the neuter nouns: дърво and село.

-/е/нце (6): детенце (Пелин, 26), ключенце (Пелин, 66), магаренце (Пелин, 8), момченце (Пелин, 44), опашченце (Пелин, 109), пиленце (Пелин, 13)

This suffix adds to the meaning of the basic noun, apart from the feature of 'physical diminution', the additional connotative component of 'tenderness'.

In the diminutives детенце, магаренце, момченце, пиленце no change of gender is detected, because the basic non-diminutive nouns are in the neuter gender: deте, магаре, момче, пиле.

A change of gender is registered in опашченце и ключенце, whose basic nouns are, опашка - in the feminine and ключ in the masculine. In these lexemes a double diminution appears, because to the combinations of the lexical bases are added the combinations of two suffixes, as seen below:

опашка > опашче > опашченце, the suffixes -че + -нце, with -ка apocope

ключ > ключе > ключенце, the suffixes -е + -нце

That is why in these diminutives an additional connotative component 'tenderness' is supplied to the meaning of the basic noun apart from the feature 'physical diminution'.

In Plural - 1

-(и)чки (1): очички (Пелин, 65)

This word exists only as Pluralia Tantum, because the suffix is added towards the plural form of the basic non-diminutive and neuter noun $о 4 u$.

3.2. In the German text there are $\underline{\mathbf{3}}$ diminutive nouns, as follows: In the singular: $\mathbf{3 3}$

3.2.1. Masculine -0 


\subsubsection{Feminine $\mathbf{- 1}$}

-ette (1): Zigarette (H. Grantsch., 44)

This noun form is a loan word from French, in the feminine, but also represents a diminutive function (Fleischer/Barz, 181).

\subsubsection{Neuter $\mathbf{- 2 7}$}

-chen (27): Beinchen (Pelin, 12), Eichhörnchen* (Pelin, 19), Erdhäufchen* (Pelin, 53), Eselchen (Pelin, 6), Flüßchen* (Pelin, 80), Härrchen* (Pelin, 56), Häuschen* (Pelin, 22), Heimatstä dtchen* (Pelin, 102)

Kerlchen (Pelin, 71), Köpfchen* (Pelin, 83), Mäuerchen* (Pelin, 7)

Mütterchen* (Pelin, 30), Plätzchen* (Pelin, 68), Schlückchen* (Pelin, 47), Schlüsselchen (Pelin, 58), Schränkchen* (Pelin, 56), Schwänzchen* (Pelin, 96), Söhnchen* (Pelin, 23), Städtchen* (Pelin, 5), Steinchen (Pelin, 33), Sträußchen* (Pelin, 87), Teufelchen (Pelin, 7), Tierchen (Pelin, 8), Tröpfchen* (Pelin, 101), Türchen (Pelin, 26), Wäldchen* (Pelin, 8), Weilchen (Pelin, 37), Wölkchen* (Pelin, 80).

The suffix is most commonly encountered in the diminutive forms of German. In the lexemes with the sign * a definite mutation is observed; in German this is known as Umlaut, also rendering account -en apocope in the Erdhaufen > Erdhäufchen, -e apocope in Weile > Weilchen $и$ Wolke $>$ Wölkchen, as well as -a- apocope in Haar $>$ Härchen.

In most diminutives there is a shift in their gender

- from masculine to neuter (17): Eichhorn > Eichhörnchen, Erdhaufen $>$ Erdh $\underline{a ̈ u f c h e n, ~ E s e l ~}>$ Eselchen, Fluss $>$ Flüßchen, Kerl $>$ Kerlchen, Kopf $>$ Köpfchen, Platz > Plätzchen, Schluck > Schlückchen, Schlüssel > Schlüsselchen, Schrank > Schränkchen, Schwanz > Schwänzchen, Sohn > Söhnchen, Stein > Steinchen, Strauß > Sträußchen, Teufel > Teufelchen, Tropfen $>$ Tröpfchen, Wald > Wäldchen;

- from feminine to neuter (6): Heimatstadt > Heimatstädtchen, Mauer > Mäuerchen, Mutter > Mütterchen, Stadt > Städtchen, Tür > Türchen, Weile $>$ Weilchen, Wolke $>$ Wölkchen.

In the following diminutives there is no shift of gender, because the initial nouns are in the neuter (4): Bein > Beinchen, Haar > Härchen, Haus $>$ Häuschen, Tier > Tierchen.

This diminutive suffix can be added to the meaning of the basic noun and apart from the feature 'physical diminution' an additional connotative component is detected with the features of 'tenderness', 'sym- 
pathy', 'mockery', 'irony', 'disdain' etc., which depends on the particular context and additional lexical elements such as attributes and others.

-lein (6): Äuglein* (Pelin, 56), Bächlein* (Pelin, 47), Eidechslein (Pelin, 8), Löchlein* (Pelin, 58), Mäuslein* (Pelin, 64), Zwerglein (Pelin, 53).

This suffix is more rarely found today in the diminutive forms of German. In the lexemes with the sign * a regular mutation is found, which in German is Umlaut, Auge > Äuglein, Bach > Bächlein, Loch > Löchlein, Maus $>$ Mäuslein, and also an $-e$ apocope is observed in Eidechse $>E i$ dechslein and Auge $>$ Äuglein.

Here also we have a shift in the gender

- from masculine to neuter (2): Bach > Bächlein, Zwerg > Zwerglein

- from feminine to neuter (2): Eidechse $>$ Eidechslein, Maus $>$ Mäuslein

In the following diminutives there is no shift in gender, because the initial nouns are in the neuter (2): Auge > Äuglein, Loch > Löchlein.

B Plural - 0

\section{Conclusions of the study:}

4.1. Similarities between the morphonological exponents in the Bulgarian and German diminutives on the basis of the analysed texts.

4.1.1. Both languages belong to the Indo-European language group, which is characteristic of most of the European languages.

4.1.2. In both languages the diminutive nouns are formed by affixation, where the suffixes are added to the base of the lexeme, and often connected by inner flexion (mutation - Umlaut, apocope, palatalization).

4.1.3. In both languages mutation (Umlaut) exists.

4.1.4. In both languages apocope takes place.

4.1.5. In the two languages there is a different distribution of the diminutives by their suffixes.

4.1.6. In both languages there is a shift of gender when applying diminution to the nouns.

4.2. Differences, detected in the morphonological indexes within the paradigms of the Bulgarian and German diminutive nouns on the basis of the analysed texts: 
4.2.1. While the Bulgarian language belongs to the Southern Slavic group, the German language represents the Western Germanic language group, which derives from the different geographic situation of the respective bearers of the languages in Europe. The Bulgarian language is defined as rather analytical, and the German - as a synthetic language, however the paradigm of the diminutive forms in Bulgarian definitely underlines its synthetic character.

4.2.2. The Bulgarian language demonstrates a much richer system of diminutive suffixes compared with the German language. In Bulgarian there are 11 suffixes for diminution: 3 for masculine, 4 for feminine and 4 for neutral, as well as 1 for the plural, while in German only 2 suffixes for the neuter are registered and 1 form for the feminine is borrowed as a form with a 'French' diminutive meaning.

4.3.2. Mutation Umlaut is typical of German, there are 22 in total out of 33 German diminutive nouns, while the number of Bulgarian cases is 2 . This is the result of the peculiar system of rules in German word formation.

4.2.4. The cases of apocopes in Bulgarian are 34: $6-e, 2-0,1-b, 22$ $-a, 3-e u$, and in German only 6.

4.2.5. In Bulgarian, in the masculine there are 5 diminutives, in the feminine -23 , and in the neuter - 39, in the plural - 1. In German they are only in the neuter.

4.2.6. In Bulgarian it is possible to retain the gender form - with the diminutive suffixes which preserve the masculine and feminine.

4.2.7. In Bulgarian the palatization of consonants is regularly found, which is characteristic of the Slavic languages.

4.2.8. Accent in Bulgarian is important, it is flexible and moving and often plays word formation role; this feature is also characteristic of some Slavic languages, for example, Russian.

4.2.9. In Bulgarian there are clearly distinguished demarcation and productivity of the diminutive suffixes from all three genders, and more rarely in the singular and plural; this again is characteristic of the Slavic languages.

4.2.10. The final ratio of the diminutive nouns is 68 to: 33 or $67 \%$ for Bulgarian diminutives and 33\% for the German. 


\section{Филологија културе}

The fact of the existence of similarities and differences in the list of features in languages testifies to varied reality, where every human language originates and develops. Each language has a different semantic use of diminutives and this is illustrated by the diversity and multiplicity of the lexical systems, which can be assessed as a reflection of the respective people's culture. Because of this it is important to study diminutives as communication tools with specific features.

Пелин, Елин. Ян Бибиян. Невероятните приключения на едно хлапе. София, Народна младеж, 1969.

Pelin, Elin. Jan Bibijan Unwahrscheinliche Abenteuer eines Lausbuben. Übers. aus dem Bulg. Hilde Grantscharowa. Berlin, Altberliner Verlag Lucie Groszer, 1962.

Андрейчин, Любомир. Основна българска граматика. София, Наука и изкуство, 1978.

БАН - Морфология. В: Граматика на съвременния български книжовен език. Том II. София, Издание на БАН, 1983.

Васева, Иванка. Стилистика на превода. София, Наука и изкуство, 1989.

Велева, Бисерка. Умалителните съществителни в приказките на Ангел Каралийчев и обучението по чужд език в контекста на междукултурна комуникация. В: Чуждоезиковото обучение в контекста на интеркултурната комуникация. Foreign Language Teaching in the Context of Intercultural Communication. Велико Търново, IVIS Publishing, ISBN 978-954-2968-77-1, 2014, 239-248.

Димитрова, Милка. Умалителните имена в книжовния български език. В: Известия на ИБЕ. Кн. VІ. София, Издателство на БАН, 1959, 258-319.

Кръстев, Боримир. Умалителността в българския език. София, 1976.

Ницолова, Руселина. Денотативни и конотативни признаци в звачението на диминутивите в българския език. Във: Wortbildung der Deminutiva aus abstrakten Substantiven im Bulgarischen: Paper presented at the 2nd Vienna Workshop on Affix Order. Vienna, 15-16 June 2009.

Радева, Василка. В света на думите. София, 2007.

Duden. Grammatik der deutschen Gegenwartssprache. In: Der Duden in 10 Bänden. Bd.4., 4. Aufl. Mannheim, 1984, 459-461.

Fleischer, Wolfgang/Barz, Irmhild. Wortbildung der deutschen Sprache. Unter Mitarbeit von Marianne Schröder. 2., durchgesehene und ergänzte Auflage, Tübingen, Max Niemeyer Verlag, 178-182, 221-222.

Henzen, Walter. Deutsche Wortbildung. Tübingen, Max Niemeyer Verlag, 1957, 140-155. 
Schmidt, Wilhelm. Deutsche Sprachkunde. Berlin, Volk und Wissen, 1959, 248-251.

Wellmann, Hans. Das Substantiv. In: Deutsche Wortbildung. Typen und Thendenzen in der Gegenwartssprache. Sprache der Gegenwart. Bd. XXXII. Düsseldorf, Schwann, 1975, 123-135.

SiM: Sprachen interaktiv: Magisterarbeit. Interkultirelle Kommunikation und interkulturelles Lernen. 1-9, www.spracheninteraktiv.de/magister/kapitel4.html. Accessed 14 Dec. 2016.

Держанский Уменьшительные имена pluralia tantum в русском и болгарском языках. БАН. http://www.dialog-21.ru/media/2500/derzhanski.pdf Accessed 05 Dec. 2016.

\section{Валентин Петрусенко Бисерка Велева \\ Универзитет у Софији „Свети Климент Охридски“}

\section{Резюме}

Умалителните съществителни са неизменна част от лексикалното богатство на езиците. Между езиците съществуват различия по отношение на количеството, морфо-семантичните характеристики и употребата на умалителните съществителни имена. Като езикови единици в процеса на комуникация те се проявяват с определен набор от общи и специфични белези. Въпросната специфика на деминутивите е характерна за всеки език и тя е особеност, по която езиците се различават, както по отношение на системата от езикови средства, така и по употребата в реалната реч. Това е свързано с прилики и разлики в културата на носителите на езиците. Фактът за различието в набора от белези в отделните езици сведетелства за многообразието и поливариантността на лексикалните езиковите системи, както и за извънезиковата реалност, в която възниква и се развива всеки език.

Предмет на настоящата разработка са умалителните съществителни, ексцерпирани от романа за деца, написан от Елин Пелин “Ян Бибиян. Невероятните приключения на едно хлапе" и от превода му на немски език. Това изследване е част от един по-обширен контрастивен лингвистичен анализ на българските и немски умалителни съществителни, установени в различни литературни българско- и немскоезични творби и техните преводи съответно на другия език.

Целта на това проучване е да потвърди наблюденията и изводите относно преводимостта на деминутивите от български на немски език, някои преводачески трансформации в качеството на механизми за компенсиране на междуезиковите несъответствия, явления, които се дължат на многообразието на различните култури. 